\title{
Use of Molasses and Distillery Slops with Sulfur for the Reclamation of a Saline-Sodic and a Sodic Soil from Puerto Rico
}

\section{Raúl Pérez Escolar ${ }^{1}$}

\section{INTRODUCTION AND REVIEW OF LITERATURE}

The use of sulfur in reclamation of saline-sodic and sodic soils is known as one of the fundamental practices used (4). ${ }^{2}$ It is recognized, however, that sulfur acts quite slowly in ameliorating these conditions. Additions of organic matter per se with sulfur to these soils are of little direct value to Thiobacillus thiooxidans which has been shown to derive its energy from the oxidation of sulfur. Acevedo, Bonnet, and Ortíz (1) have shown, nevertheless, that a sulfur and sugarcane bagasse treatment is conducive to a more rapid and effective reclamation of a saline-sodic soil than either a sulfur or a bagasse treatment alone. Bagasse additions are effective in increasing the absorption of water and salts by the soil, thus lowering the osmotic concentration, and improving aeration conditions. It is believed that, during the decomposition of bagasse with the subsequent evolution of carbon dioxide, acid conditions are created which apparently are favorable for T. thiooxidans activity.

Dhar and Mukerji (3) appear to be the only investigators who conducted experimental work using blackstrap molasses to help reclaim solonetzic soils. They claim to have brought these soils back to "normal conditions" in a period of 6 months, when molasses was applied at the rates of 30 to 40 tons to the acre. They believed that their results were caused by acidity of molasses and the organic acids, such as acetic, propionic, butyric, and lactic produced upon decomposition of the molasses. These acids acted to neutralize the bases and carbonates present in soil rich in alkali. It was also proposed that in the process, the evolution of $\mathrm{CO}_{2}$ from the molassestreated soil rendered it porous and improved its tilth. It was observed that microbial activity, which is normally low at the prevailing $\mathrm{pH}$ of sodic soils, was considerably increased. Soil nitrogen content was increased from 0.0025 to 0.05 percent. This increase in soil nitrogen occurred because of greater fixation of atmospheric nitrogen by micro-organisms.

To determine the effects that molasses and distillery-slops additions might have on the use of sulfur in reclaiming a saline-sodic and a sodic

${ }^{1}$ Associate Soil Scientist, Agricultural Experiment Station, University of Puerto Rico, Río Piedras, P. R.

${ }^{2}$ Italic numbers in parentheses refer to Literature Cited, p. 65. 
soil, a greenhouse experiment was conducted, using two soils obtained from southwestern Puerto Rico.

\section{MATERIALS AND METHODS}

In these tests No. 6 metal cans, with openings in the bottom, were filled with 2.3 pounds of soil. The soils used, in separate experiments, were the saline-sodic Fe (Fe or Faith, in English, is simply the name of the soil; it does not imply "iron" clay) and the nonsaline alkali Guanica clay. Their physical, chemical, and mineralogical properties are shown in table 1.

Prior to placing the soils in the cans, the field samples were passed through a 2-mm. sieve. Since these two soils had been sterilized after arrival in the United States, they were inoculated with $2 \mathrm{~g}$. of field soil.

TABLE 1.-Physical, chemical, and minerological properties of $\mathrm{Fe}$ and Guanica clays used

\begin{tabular}{|c|c|c|c|c|c|c|c|c|c|c|}
\hline $\begin{array}{c}\text { Name of } \\
\text { clay }\end{array}$ & $\mathrm{pH}$ & $\left|\begin{array}{c}\text { Organic } \\
\text { matter }\end{array}\right|$ & $\mid \begin{array}{c}\text { Cation } \\
\text { ex- } \\
\text { change } \\
\text { capac- } \\
\text { ity }\end{array}$ & $\begin{array}{l}\text { Satu- } \\
\text { ration }\end{array}$ & $\begin{array}{c}\text { Con- } \\
\text { duc- } \\
\text { tivity } \\
\text { E.C. } \times \\
10^{3}\end{array}$ & $\begin{array}{l}\text { Ex- } \\
\text { change } \\
\mathrm{Na}\end{array}$ & Sand & Silt & Clay & Clay minerals \\
\hline & & Percent & $\begin{array}{c}M \text { eq. } / \\
100 \mathrm{gm}\end{array}$ & Percent & \begin{tabular}{|}
$\left(\begin{array}{l}(M m h l o s \\
\text { per } c m . .\end{array}\right.$ \\
per
\end{tabular} & Percent & Percent & Percent & Percent & Percent \\
\hline $\mathrm{Fe}$ & 8.2 & 3.00 & 47.7 & 75 & 66.7 & 43 & 16.8 & 20.6 & 62.6 & $\begin{array}{l}90 \text { Montmoril- } \\
\text { lonite } \\
10 \text { Quartz and } \\
\text { kaolinite }\end{array}$ \\
\hline Guaniea & 9.0 & 3.36 & 58.6 & 165 & 5.5 & 35 & 13.2 & 24.0 & 62.3 & $\begin{array}{l}90 \text { Montmoril- } \\
\text { lonite } \\
10 \text { Quartz and } \\
\text { kaolinite }\end{array}$ \\
\hline
\end{tabular}

The following treatments duplicated and arranged in a randomized block design were used:

1. Check.

2. Sulfur -4 tons to the acre (to meet gypsum requirement).

3. Slops application equivalent to the field-moisture capacity of the soil.

4. Slops application equivalent to field-moisture capacity of the soil plus 4 tons of sulfur an acre.

5. Molasses (20 percent by volume) application equivalent to the fieldmoisture capacity of the soil.

6. Molasses (20 percent by volume) application equivalent to the fieldmoisture capacity of the soil plus 4 tons of sulfur per acre.

One milliliter of a Thiobacillus thiooxidans culture was added to the treatments which received sulfur applications.

Even though it was not intended to evaluate the treatments in terms of 
crop yield, three test crops were used. In both Fe clay and Guanica clay soils, corn (variety N. J. 109) was planted as the first two crops and snapbeans (variety Bountiful) were planted as the third crop. Before seeding the Fe clay (saline-sodic soil) soil, 11/2 acre-feet of water was passed through the cans practically to remove free salts.

Prior to seeding each of the crops, a complete fertilizer (5-10-10) was added at a rate equivalent to a ton per acre.

After the first corn crop was harvested, the hydraulic conductivity of the soil core and the $\mathrm{pH}$ value of the top 3 inches were determined. Only crop yields and hydraulic conductivity were measured in the second corn crop. Acidity was not determined in the soil after the removal of the second crop, in spite of the fact that it was intended to follow the course of $\mathrm{pH}$ changes produced by the action of $T$. thiooxidans. This was because of the relatively low volume of soil used in this test.

At the end of the third crop, the $\mathrm{pH}$ value, hydraulic conductivity, and exchangeable-sodium contents were determined in each soil core.

The $\mathrm{pH}$ values of the soils were estimated electrometrically on a $2: 1$ soil to distilled-water suspension, employing a Beckman pH-meter.

Specific resistance of the saturation extracts was determined with a Wheatstone bridge with a cell constant of 1.0. Electrical conductivity was calculated by multiplying the measured negative resistance by the cell constant.

Exchangeable sodium percentage was estimated by plotting in a nomogram the values of milliequivalents of $\mathrm{Na}$ and $\mathrm{Ca}+\mathrm{Mg}$ per liter.

Organic matter of the soil was determined by the chromic acid reduction method (8).

The barium acetate method (6) was used in the determination of cation-exchange capacity.

Particle-size distribution was determined by the pipette method, as modified by Kilmer and Alexander (10).

Hydraulic conductivity of the water-saturated cores was measured by a modified method of Bower (2).

In the identification of clay minerals the less than $2 \mu$-size fraction was used. An RCA-Leiments crystalloflex IV X-ray diffractometer with an automatic recording device was used.

\section{RESULTS AND DISCUSSION}

\section{SODIC SOIL-GUANICA CLAY}

The germination percentages, dry-weight yields of corn, the hydraulicconductivity and $\mathrm{pH}$ values of the soil after the removal of the first crop grown on the Guanica clay are presented in table 2. 
Seedlings had not emerged from the soil in either the check or the sulfur treatment when the counts were made. The germinations on all other treatments were superior to those in these two treatments. With the molasses as well as with the sulfur-slops treatments, germination appeared to be higher than with slops or sulfur and molasses treatments, but the values were not significant. Although the general appearance of corn, even in the slops, molasses, sulfur and slops, and molasses-sulfur treatments was not too good, despite the good drainage conditions, differences in growth and dry-

TABLE 2.-Germination, dry-weight yields of corn, hydraulic conductivity, and $p H$ values of Guanica clay soil after the removal of the first corn crop

\begin{tabular}{l|c|c|c|c}
\hline \multicolumn{1}{c|}{ Treatment } & Germination & Dry-weight yields & $\begin{array}{c}\text { Hydraulic } \\
\text { conductivity }\end{array}$ & $\mathrm{pH}^{1}$ \\
\cline { 2 - 3 } & Percent & Gm. & (In./Hr.) & \\
Check & 0 & 0.25 & $<0.005$ & 9.2 \\
Sulfur & 0 & .28 & $<.005$ & 7.9 \\
Slops & 50 & 1.91 & 1.75 & 9.0 \\
Sulfur and slops & 75 & 2.51 & .75 & 7.6 \\
Molasses & 75 & 5.76 & .25 & 9.1 \\
Sulfur and molasses & 50 & 3.14 & 1.76 & 6.6 \\
\hline
\end{tabular}

1 The $\mathrm{pH}$ value was measured on soil from the top 3 inches of the pots.

Levels of significance ${ }^{2}$

5 percent

Germination

Dry-weight yields

Hydraulic conductivity
563421

564321

634521
1 percent

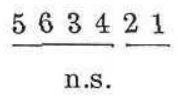

634521

${ }^{2}$ Any 2 means not underscored by the same line are different at the indicated level of significance: Treatments: 1 , check; 2 , sulfur; 3 , slops; 4 , sulfur and slops; 5 , molasses; 6 , molasses and slops.

weight yields were obtained. The highest yields were obtained from the molasses treatment despite the high soil $\mathrm{pH}$. It was expected that the sulfur-molasses treatment, with a soil $\mathrm{pH}$ value of 6.6 should have produced the best yields. Further, the soil of this treatment had the highest hydraulic conductivity value. It should be remembered, however, that although the sulfur-molasses treatment produced the greatest change in soil acidity, it also was responsible for bringing appreciable amounts of $\mathrm{Ca}$ into solution from solid $\mathrm{CaCO}_{3}$, which was present in the soil. This may have produced an imbalance of ions which results in lower yields than from the molasses treatment.

Soil $\mathrm{pH}$ values in all treatments receiving sulfur additions were ap- 
preciably lowered at the end of 30 days when the crop was harvested. It is extremely doubtful, however, that the drop in soil $\mathrm{pH}$ value from 9.2 to 7.9 noted on the sulfur treatment was completely attributable to the oxidation of sulfur by $T$. thiooxidans. It is believed that this $\mathrm{pH}$ change may have been also partly caused by the hydrolyses of acid fertilizers added to the soil prior to planting.

The large decrease in soil $\mathrm{pH}$ value in the sulfur-molasses treatment can be explained. The addition of molasses, with its high sugar content, plus other easily decomposable carbohydrates which can yield organic acids,

TABLE 3.-Germination, dry-weight yields of corn, and hydraulic conductivity values of the Guanica clay soil after the removal of the second corn crop

\begin{tabular}{l|c|c|c}
\hline \multicolumn{1}{c|}{ Treatment } & Germination & Dry-weight yields & $\begin{array}{c}\text { Hydraulic } \\
\text { conductivity }\end{array}$ \\
\cline { 1 - 1 } Check & Percent & Gm. & (In./hr.) \\
Sulfur & 25 & 0 & $<0.005$ \\
Slops & 38 & 0 & $<.005$ \\
Sulfur and slops & 75 & .75 & .15 \\
Molasses & 63 & .88 & 4.15 \\
Sulfur and molasses & 50 & 1.81 & 1.30 \\
& 100 & 2.72 & 4.16 \\
\hline
\end{tabular}

Levels of Significance ${ }^{2}$

5 percent

1 percent

\begin{tabular}{|c|c|c|}
\hline Germination & 6345251 & 634521 \\
\hline Dry-weight yields & 654321 & 654321 \\
\hline Hydraulic conductivity & 6445321 & $\begin{array}{llllll}6 & 4 & 5 & 3 & 2 & 1\end{array}$ \\
\hline
\end{tabular}

${ }^{2}$ Any 2 means not underscored by the same line are different at the indicated level of significance: Treatments: 1 , Check; 2 , sulfur; 3 , slops; 4 , sulfur and slops; 5 , molasses; 6 , molasses and slops.

may have been responsible for the reduction in soil $\mathrm{pH}$, as well as for producing conditions stimulating the activities of $T$. thiooxidans.

The data obtained with the second crop of corn grown on the Guanica clay are listed in table 3 . The sulfur-molasses treatment produced the greatest yield, and had the highest germination of all. However, it should be pointed out, that all slops or molasses treatments were better than the check treatment. The hydraulic conductivity value of soil from this treatment was more than twice the value obtained after the removal of the first crop. This was also true of the sulfur-slops treatment, although corn growth was not as good.

Hydraulic conductivity values did not increase in the sulfur treatment. 
A rather sharp drop in water movement, as indicated by hydraulic conductivity value, occurred in the slops treatment. This behavior can probably be explained by the fact that the active soil-aggregating residue in the slops is alkaline-soluble and because the $\mathrm{pH}$ value of the soil in this treatment was 9.0; solution of the active residue occurred. A more detailed discussion of this point is presented in the description of the active soil-aggregating residue found in the slops (7).

TABLE 4.-Germination, dry-weight yields of snapbean tops, and hydraulic conductivity, $p H$, and exchangeable sodium percentage value in Guanica clay soil after the removal of the third crop

\begin{tabular}{|c|c|c|c|c|c|}
\hline Treatment & $\begin{array}{l}\text { Germin- } \\
\text { ation }\end{array}$ & $\begin{array}{c}\text { Dry-weight } \\
\text { yields }\end{array}$ & $\begin{array}{l}\text { Hydraulic } \\
\text { conductivity }\end{array}$ & $\mathrm{pH}^{1}$ & E.S.P. \\
\hline & Percent & $\mathrm{Gm}$. & (In./hr.) & & \\
\hline Check & 0 & 0.20 & $<0.005$ & 8.6 & 37.4 \\
\hline Sulfur & 25 & .28 & $<.005$ & 7.8 & 38.4 \\
\hline Slops & 25 & .90 & .15 & 8.6 & 16.8 \\
\hline Sulfur and slops & 100 & 2.29 & 10.30 & 7.6 & 6.5 \\
\hline Molasses & 88 & 2.60 & 2.96 & 8.3 & 10.3 \\
\hline Sulfur and molasses & 100 & 2.27 & 7.90 & 7.6 & 6.5 \\
\hline
\end{tabular}

${ }^{1} \mathrm{pH}$ was measured in the whole soil core.

Levels of Significance ${ }^{2}$

5 percent

1 percent

Germination

$\frac{645}{546} \frac{32}{365} \frac{21}{321}$

6455321

Dry-weight yields

Hydraulic conductivity

465321

546321

465321

${ }^{2}$ Any 2 means not underscored by the same line are different at the indicated level of significance: Treatments: 1 , Check; 2 , sulfur; 3 , slops; 4 , sulfur and slops; 5 , molasses; 6 , molasses and slops.

Data concerned with the third crop, snapbeans, grown on the Guanica clay are listed in table 4 . Germination values were significantly higher in the sulfur-slops, sulfur-molasses, and molasses treatments when compared with the sulfur and control treatments.

Dry-weight yields of bean tops were higher in the sulfur-slops, sulfurmolasses, and molasses treatments when compared with the slops, sulfur, and control treatments, among which there were no differences. The hydraulic-conductivity values of the sulfur-slops, sulfur-molasses, and molasses treatments were considerably higher than in the other treatment. The most marked change was obtained in the sulfur-slops treatment. The $\mathrm{pH}$ values of the soils receiving sulfur-bearing treatments were not as low as 
after the removal of the first crop. It should be pointed out, however, that the initial $\mathrm{pH}$ values were estimated on soil taken from the top 3 inches of the pots, whereas the last values represent the $\mathrm{pH}$ of the complete soil column.

Further, the sulfuric acid produced by $T$. thiooxidans was probably neutralized as time of cropping progressed, especially in this soil which has a high potential alkalinity. The values obtained for the exchangeable sodium were encouraging. Sulfur-molasses, sulfur-slops, and molasses treatments caused the greatest changes. It is surprising that even

TABLE 5.-Germination, dry-weight yields of corn, and $p H$ and hydraulic conductivity values of Fe clay soil after the removal of the first corn crop ${ }^{1}$

\begin{tabular}{|c|c|c|c|c|}
\hline Treatment & Germination & $\begin{array}{l}\text { Dry-weight } \\
\text { yields }\end{array}$ & $\mathrm{pH}$ & $\begin{array}{l}\text { Hydraulic } \\
\text { conductivity }\end{array}$ \\
\hline & Percent & $\mathrm{Gm}$. & & (In./hr.) \\
\hline Check & 63 & 3.23 & 8.3 & 0.04 \\
\hline Sulfur & 63 & 2.68 & 7.3 & .22 \\
\hline Slops & 75 & 3.22 & 8.2 & .26 \\
\hline Sulfur and slops & 63 & 1.84 & 7.1 & .93 \\
\hline Molasses & 87 & 4.14 & 7.8 & .82 \\
\hline Sulfur and molasses & 100 & 4.02 & 6.8 & 1.11 \\
\hline
\end{tabular}

${ }^{1}$ Levels of significance ${ }^{2}$

5 percent

Germination

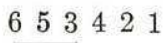

1 percent

Dry-weight yields

n.s.

n.s.

Hydraulic conductivity

$\underline{645321} \quad \underline{645321}$

${ }^{2}$ Any 2 means not underscored by the same line are different at the indicated level of significance: Treatments: 1 , Check; 2 , sulfur; 3 , slops; 4 , sulfur and slops; 5 , molasses; 6 , molasses and slops.

though the slops treatment failed to produce large increases in crop yields and changes in hydraulic conductivity in the second and third crops, the exchangeable-sodium percentage was reduced by more than onehalf its initial value.

\section{SALINE-SODIC SOIL-FE CLAY}

Table 5 presents data obtained on the first corn crop, and values for hydraulic conductivity and $\mathrm{pH}$ on the $\mathrm{Fe}$ (Faith) clay after the removal of the crop. The sulfur-molasses treatment was responsible for the best germination. Hydraulic conductivity values increased, and the $\mathrm{pH}$ changes were the most marked under this treatment. The $\mathrm{pH}$ values dropped from 
8.3 to 6.8 . Even though differences exist in crop yields, these are not significant. The movement of water in the sulfur treatment was affected favorably, as indicated by the increase in hydraulic conductivity from 0.04 in check treatment to 0.22 inches an hour in the sulfur treatment. Even though the $\mathrm{Fe}$ clay contains much exchangeable sodium, the movement of water through a column of it was not as slow as in the Guanica clay. This is because the salt content of the Fe clay is higher than that in the Guanica clay, and the soil colloidal particles are well flocculated.

\section{TABLE 6-Germination, dry-weight yields of corn, and the hydraulic conductivity} values of the Fe clay soil after the removal of the second corn crop ${ }^{1}$

\begin{tabular}{l|c|c|c}
\hline \multicolumn{1}{c|}{ Treatment } & Germination & Dry-weight yields & $\begin{array}{c}\text { Hydraulic } \\
\text { conductivity }\end{array}$ \\
Check & Percent & Gm. & (In./hr. $)$ \\
Sulfur & 38 & 3.02 & 0.05 \\
Slops & 25 & 2.39 & .25 \\
Sulfur and slops & 88 & 3.33 & .26 \\
Molasses & 75 & 2.81 & 3.00 \\
Sulfur and molasses & 88 & 3.75 & 3.51 \\
& 100 & 2.82 & 4.11 \\
\hline
\end{tabular}

${ }^{1}$ Levels of significance ${ }^{2}$

5 percent

Germination

653412

1 percent

Dry-weight yields

n.s.

n.s.

Hydraulic conductivity

654321

n.s.

${ }^{2}$ Any 2 means not underscored by the same line are different at the indicated level of significance: Treatments: 1 , Check; 2, sulfur; 3 , slops; 4, sulfur and slops; 5 , molasses; 6 , molasses and slops.

Data concerned with the second crop, corn, on the Fe clay soil are presented in table 6. Germination and seedling emergence was the best in the molasses-sulfur treatment, followed by slops, molasses, and sulfurslops treatments.

No differences in dry-weight yields were noted between the various treatments.

The molasses-sulfur treatment effected the largest increase in hydraulic conductivity. Molasses and sulfur, and slops treatments also improved water movement in the Fe-clay treatments as shown by the increases in hydraulic conductivities.

The final crop grown on the Fe-clay soil was snapbeans. Yields, germination, and data on the properties of the soil after the removal of the crop are listed in table 7. 
Germination values of the last bean crop in the Fe clay were significantly higher in the sulfur-slops and molasses treatments than in the control. A 100 -percent emergence was obtained. No differences were noted in yields of snapbean tops that were significant because of the extreme variations between replicates of the various treatments. Marked changes in soil $\mathrm{pH}$ were noted that were similar to those obtained on the Guanica clay soil, especially with the sulfur-bearing treatments.

Sulfur-slops, sulfur molasses, and sulfur treatments improved water permeability. This was also true for the slops and molasses treatment.

TABLE 7.-Germination and dry-weight yields of snapbean tops, and $p H,{ }^{1}$ hydraulic removal of the crop ${ }^{2}$

\begin{tabular}{l|c|c|c|c|c}
\hline \multicolumn{1}{c|}{ Treatment } & $\begin{array}{c}\text { Germina- } \\
\text { tion }\end{array}$ & $\begin{array}{c}\text { Dry-weight } \\
\text { yields }\end{array}$ & $\mathrm{pH}$ & $\begin{array}{c}\text { Hydraulic } \\
\text { conductivity }\end{array}$ & $\begin{array}{c}\text { Exchangeable } \\
\text { Sodium }\end{array}$ \\
\cline { 1 - 2 } & $\begin{array}{c}\text { Percent } \\
\text { Check }\end{array}$ & Gm. & & $($ In./hr. $)$ & Percent \\
Sulfur & 50 & 1.43 & 8.5 & 0.44 & 17.1 \\
Slops & 63 & 2.47 & 7.5 & 3.81 & 18.1 \\
Sulfur and slops & 63 & 2.08 & 8.1 & 4.10 & 22.1 \\
Molasses & 100 & 2.27 & 7.3 & 11.17 & 4.5 \\
Sulfur and molasses & 100 & 2.85 & 7.8 & 7.51 & 23.2 \\
& 88 & 2.48 & 7.2 & 10.16 & 4.5 \\
\hline
\end{tabular}

${ }^{1} \mathrm{pH}$ was measured in the whole soil core.

Levels of significance ${ }^{2}$

\begin{tabular}{|c|c|c|}
\hline \\
\hline & 5 percent & 1 percent \\
\hline Germination & $\begin{array}{llllll}5 & 4 & 6 & 3 & 2 & 1\end{array}$ & n.s. \\
\hline Dry-weight yields & n.s. & n.s. \\
\hline Hydraulic conductivity & 4655321 & 465321 \\
\hline
\end{tabular}

${ }^{2}$ Any 2 means not underscored by the same line are different at the indicated level of significance: Treatments: 1 , check; 2 , sulfur; 3 , slops; 4 , sulfur and slops; 5 , molasses; 6 , molasses and slops.

After the removal of the third crop, the hydraulic conductivity of the check had also improved considerably above its initial value.

The question arises as to why the slops treatment produced such a relatively high increase in hydraulic conductivity on the Fe clay soil, when this treatment applied to the Guanica clay soil was relatively ineffective. The explanation for this difference is probably related to the high solublesalt content of the Fe clay soil when compared with the Guanica clay soil. The high soluble-salt content may have produced a "salting-out effect" on the clay-slops complex and prevented its dispersion. Furthermore, root penetration to favor water movement and the rather acid conditions produced by the fertilizer applied must have improved soil conditions. 
Exchangeable sodium values were, as expected, lower in sulfur-slops and sulfur-molasses treatments. It is interesting to note that, although the percentage of exchangeable sodium of the check treatment was lowered considerably, no marked effects were obtained on the hydraulic-conductivity values and water movement was quite slow. This stresses the importance of the stability imparted by the slops and molasses treatments to the soil which showed higher exchangeable sodium values and yet allowed water to move considerably faster through these soils than through the control.

\section{SUMMARY}

Data are presented on the effects of the use of molasses and distillery slops in conjunction with sulfur for the reclamation of a saline-sodic and a sodic soil from southwestern Puerto Rico.

Results show that, in a sodic Guánica clay soil, corn yields were higher under the molasses treatment in the first corn crop, sulfur-slops and sulfur molasses in the second corn crop, and molasses, sulfur-slops, and sulfur molasses in the third crop, namely, snapbeans. Hydraulic conductivity values were markedly increased in the sulfur-slops and sulfur molasses treatments and removal of harmful exchangeable sodium was possible throughout the three crops. This was probably because of better water movement and the fact that more $\mathrm{Ca}$ ions were brought into circulation to displace adsorbed sodium.

The experiments conducted on the saline-sodic Fe (Faith) clay soil followed about the same pattern of crop yields, hydraulic conductivity, and removal of exchangeable sodium of the Guánica clay soil. On the check plots, however, replacement of adsorbed sodium was rather pronounced for several possible reasons. These are: The soil had excess soluble salts which, for some time at least, maintained the colloids in a flocculated state. The soil column was rather short, 6 inches, and the hydrolysis of fertilizer salts must have brought into circulation $\mathrm{Ca}$ ions in an amount such as to replace considerable adsorbed sodium.

Since Thiobacillus thiooxidans derives its energy from the oxidation of sulfur alone it is believed that the enhanced oxidation of sulfur must have been caused by created aeration and somewhat acid conditions which favored the bacteria.

\section{RESUMEN}

Se presentan los datos obtenidos del uso de mieles finales y mosto, conjuntamente con azufre elemental, en la reclamación de un suelo salinosódico y otro suelo sódico de la Región Suroeste de Puerto Rico.

Los resultados demuestran que los rendimientos de maíz fueron más 
altos en el suelo sódico Guánica arcilloso con el tratamiento de miel, en la primera siembra. Los tratamientos de azufre con miel y azufre con mosto produjeron los más altos rendimientos en la segunda siembre de maíz y en la subsiguiente siembra de habichuelas. Los valores de conductividad hidráulica aumentaron marcadamente con los tratamientos de azufre con mosto y azufre con miel, y la remoción del sodio intercambiable fué posible durante las tres cosechas. La remoción del sodio se debió probablemente a un mejor movimiento del agua y a una mayor circulación de iones de $\mathrm{Ca}$ para desplazar el sodio sustitúble.

Los experimentos efectuados en un suelo salino-sódico $\mathrm{Fe}$ arcilloso siguieron el mismo patrón de rendimiento de maíz y habichuelas, conductividad hidráulica y remoción del sodio intercambiable, que el suelo Guánica arcilloso. En el tratamiento testigo, sin embargo, la remoción del sodio intercambiable fué más marcada por varias razones. Las razones fueron cono sigue: El suelo tenía un exceso de sales solubles que mantuvieron por algún tiempo los coloides floculados; la columna del suelo era más bien corta, de 6 pulgadas; y la hidrólisis de las sales de abono deben haber causado una circulación de iones de $\mathrm{Ca}$, suficiente para desplazar una buena porción del sodio intercambiable.

En vista de que $T$. thiooxidans deriva su energía de la oxidación del azufre, se cree que esta energía aumentó al crearse condiciones de aeración y zcidez que favorecieron su actividad.

\section{LITERATURE CITED}

1. Acevedo, G., Bonnet, J. A., and Ortíz Vélez, J., Degree of reclamation of a salinesodic soil in Lajas Valley, J. Agr., Univ. P. R. 45(3): 157-71, 1961.

2. Bower, C. A., Technique for determining the permeability of soil cores obtained with the Lutz sampler, Agron. J. 42: 55-6, 1950.

3. Dhar, N. R., and Mukerji, S. K., Alkali soils and their reclamation, Proc. Natl. Acad. Sci., India, pp. 136-48, 1936.

4. Joffee, J. S., and McLean, H. C., Biochemical sulfur oxidation as a means of improving alkali soils, Science. 58: 53-4, 1923.

5. Kilmer, V. J., and Alexander, J. T., Methods of making mechanical analyses of soils, Soil Sci. 68: 15-24, 1949.

6. Parker, I. W., The determination of exchangeable hydrogen in soils, J. Amer. Soc. Agron., 21: 1030-39.

7. Pérez Escolar, Raúl, Separation and characterization of the active soil aggregating agent present in distillery slops. (In preparation.)

8. Walkley, A., and Blake, T. A., An examination of the Degtjareff method for determining soil organic matter and a proposed modification of the chromic acid titration method, Soil Sci. 37: 29-38, 1934. 